\title{
THE ROBO MOBILE SET REVIEW
}

\section{Soňa NERADOVÁ}

\begin{abstract}
This article provides a review of the robotics kit Robo Mobile Set. The aim of the review was considering suitability of the kit as a teaching tool for elementary and secondary schools.
\end{abstract}

Key words: review, robotics, kit, teaching tool, Robo Mobile Set, Fischertechnik

\section{RECENZE STAVEBNICE ROBO MOBILE SET}

Resumé: Článek je recenzí robotické stavebnice Robo Mobile Set. Záměrem bylo zejména posouzení stavebnice z hlediska jeji vhodnosti jako učebni pomůcky pro základní a středni školy

Klíčová slova: recenze, robotika, stavebnice, učební pomi̊cka, Robo Mobile Set, Fischertechnik.

\section{1 Úvod}

Všeobecné technické vzdělání je, či by mělo být, nedílnou součástí vzdělávání již u žáků základních škol. Je známo, že inteligence člověka se nejvíce rozvíjí již v raném dětství, proto je vhodné začít $\mathrm{s}$ technickou výchovou co nejdříve a vytvořit tak u dětí aktivní vztah $\mathrm{k}$ technice. Způsob výuky a použité pomůcky musí samozřejmě odpovídat věku dětí. Obecně je však možné říci, že technická výuka by v žádném prŕípadě neměla probíhat pouze $\mathrm{v}$ teoretické rovině, ale měla by využívat $\mathrm{v}$ co možná největší míre praktických učebních pomůcek, především stavebnic. Použití stavebnic při výuce umožňuje dětem zábavnou formou si prakticky ověřit a procvičit nabyté znalosti, zábavná forma výuky je velmi důležitá pro vytvoření kladného vztahu dětí $\mathrm{k}$ technice.

U žáků vyšších tříd základních škol, víceletých gymnázií a středních škol je vhodné hodiny technického vzdělávání zaměřit konkrétním směrem a věnovat se výuce určitého technického oboru podrobněji. Možností je mnoho, jednou z nich je zaměřit se na základy robotiky. Robotika je jedním z nejvíce se rozvíjejících oborů, její výuka může být při vhodném způsobu a vedení pro žáky a studenty značně atraktivní a povzbudit tak jejich zájem pro další studium tohoto oboru.

Robotických stavebnic $\mathrm{v}$ dnešní době existuje velké množství od jednoduchých až po propracované typy, které umožňují vytvářet a programovat složité roboty se sofistikovaným systémem ř́zení. Výběr vhodné stavebnice je jedním ze základních předpokladů pro povzbuzení zájmu žáků a studentů o robotiku, nevhodný typ stavebnice může zájem žáků spíše utlumit, príṕpadně je od zájmu o robotiku či technické obory obecně i úplně odradit. Porovnání různých typů robotických stavebnic a jejich zhodnocení zhlediska vhodnosti pro výuku na základních a středních školách není bohužel k dispozici. Tento článek si rovněž neklade za cíl porovnání různých druhů stavebnic, ale popisuje konkrétní zkušenosti autorky s robotickou stavebnicí Robo Mobile Set německého výrobce Fischertechnik.

\section{Popis stavebnice}

Balení stavebnice Robo Mobile Set obsahuje většinou plastové díly pro sestavení celkem osmi různých typů robotů (zobrazených v návodu, sestavení dalších modelů dle vlastního návrhu je samozřejmě možné), dva moduly s motorem a převodovkou pro pohon robotů, elektronickou řídící jednotku, propojovací vodiče a konektory (před prvním sestavením je nutné vodiče nastř́hat na jednotlivé kusy a opatřit na koncích konektory), CD s konfiguračním software RoboPro a dokumentací v pdf formátu, tištěnou př́ručku $\mathrm{k}$ programu a tištěný návod s názornými obrázky pro sestavování robotů. Součástí stavebnice není napájecí zdroj - akumulátor s nabíječkou má samostatné objednací číslo a je nutné objednat zvlášt', což bohužel zjistíme až z návodu stavebnice, přestože na obalu stavebnice jsou všechny typy robotů vyobrazeny včetně napájecího akumulátoru.

Další nemilou skutečností je absence českého návodu. Přiložené tištěné př́ručky i prríručky $\mathrm{v}$ pdf formátu jsou $\mathrm{k}$ dispozici $\mathrm{v}$ celkem šesti jazycích, čeština však mezi nimi není. Pro vlastní sestavení robotů není český návod v podstatě nutný, vyobrazení jednotlivých kroků je dostatečně názorné a srozumitelné (jednotlivé roboty podle nich sestavily i desetileté děti). Pro 
většinu potenciálních uživatelů však pravděpodobně bude omezením chybějící český manuál $\mathrm{k}$ dodávanému konfiguračnímu software RoboPro. Na webové adrese www.stavebnice.com je k dispozici ke stažení český návod, ten je však poměrně stručný a zdaleka nepopisuje všechny možnosti programu. Pro porovnání - originální cizojazyčné verze mají cca 150 stran, český návod 25 stran. Pro plné využití možností software RoboPro a tedy i celé stavebnice je tak nutná znalost angličtiny, němčiny nebo jiného z použitých jazyků, vhod přijdou i zkušenosti s jinými konfiguračními programy. Základním předpokladem je také dobrá uživatelská znalost PC.

\section{Mechanická a elektronická část stavebnice}

Stavebnice obsahuje cca 400 různých plastových dílů, umožňujících sestavení sedmi kolových a jednoho kráčejícího robota; dále dva komplety motor a převodovka 1:50 pro pohon robotů, řídící jednotku, čtyři dotykové senzory (mikrospínače), dva snímače světla (fototranzistory) a zdroj světla (žárovka s čočkou).

Použitý plast i zpracování mechanických dílů je poměrně kvalitní, díly nemají žádné ostré hrany a jejich sestavení nečiní obtíže, i když pro jejich vzájemné spojení zasunutím je někdy třeba vynaložit větší sílu. Sestavení robotů je vcelku rychlé a bezproblémové. Vzhledem ke krátké době používání nebylo možné zhodnotit odolnost dílů vưči opotřebení a př́ípadnému nešetrnému zacházení ze strany žáků.

Propojovací kablíky a konektory jsou barevně označeny zelenou a červenou barvou a jejich zasouvání do zdířek je bezproblémové; konektory zasunuté ve zdířkách drží a nemají tendenci k samovolnému uvolňování. Propojení motorů a senzorů $s$ ř́dící jednotkou je snadné a jednoznačné podle nákresů $\mathrm{v}$ návodu pro sestavení robotů. Jedinou výhradu je možné mít kabsenci označení polarity připojení na motorech, připojení vodičů je tak $\mathrm{v}$ některých př́padech nutné vyzkoušet, aby se motory otáčely požadovaným směrem.

Rídící jednotka se skládá z vlastní desky elektroniky, umístěné $\mathrm{v}$ průhledném plastovém krytu. Je vybavena sériovým a USB rozhraním pro připojení $\mathrm{k}$ počítači, zdířkami pro připojení motorů a senzorů a dvěma tlačítky pro reset řídící jednotky a pro spuštění nahraného programu. Celkově působí rídící jednotka profesionálním dojmem a její propojení $\mathrm{s}$ ostatními díly stavebnice je bezproblémové.

Dotykové senzory (mikrospínače) jsou rovněž vcelku bezproblémové, je pouze nutné dbát na jejich správné usazení do správné polohy (senzory jsou zasunuty $\mathrm{v}$ drážce, $\mathrm{v}$ požadované poloze nejsou žádným způsobem aretovány a v dané poloze drží pouze díky mechanickému tření a odporu, nutnému k jejich posunutí).

Totéž se bohužel nedá říci o použitých senzorech světla. Dva kusy těchto senzorů, dodaných ve stavebnici, vykazovaly značně rozdílnou citlivost. Citlivost senzorů lze ověřit i bez měřicího přístroje, pomocí funkce ,Test rozhraní“ konfiguračního software RoboPro, kdy na oba vedle sebe umístěné senzory necháme dopadat světlo $\mathrm{z}$ jednoho zdroje. Postupně zvyšujeme a snižujeme intenzitu dopadajícího světla a sledujeme odezvu senzorů. Citlivost senzorů není možné žádným způsobem nastavit, rozdílná citlivost způsobuje problémy při pokusech naprogramovat robota tak, aby sledoval tmavou čáru nakreslenou na světlém podkladu (jeden z osmi typů robotů, které lze podle návodu sestavit) - jeden ze senzorů detekoval i světlo odražené od černého povrchu, při snížení intenzity světla již druhý senzor nebyl schopen zachytit ani světlo odražené od bílého povrchu. Robot, v návodu nazvaný „hledač stopy“, tak nebyl schopen sledovat ani matnou černou textilní pásku nalepenou na bílém papíru. Navíc se citlivost senzorů ukázala nedostatečná i pro konstrukci robota, ,hledače světla“. Robot byl schopen vyhledat a sledovat světelný zdroj pouze v př́padě, kdy se paprsek světla (z ruční svítilny) zamířil v zatemněné místnosti přímo na světelné senzory robota.

\section{Software RoboPro}

Instalace software $\mathrm{z}$ dodaného $\mathrm{CD}$ je bezproblémová, rovněž bez problémů proběhl i update programu z webových stránek výrobce. Software RoboPro je za běhu stabilní a během jeho používání se nevyskytly žádné problémy v podobě zatuhnutí programu či jiné projevy nestability. Software byl instalován na počítačích (notebooky) s operačním systémem Windows XP.

Vlastní programování je řešeno formou „drag and drop“ - výběru a spojování grafických symbolů na pracovní ploše programu do vývojového diagramu řídícího algoritmu robota. Případná změna parametrů (časování - zpoždění, výběr konkrétního vstupu či výstupu apod.) je možná v dialogovém okně, které se objeví po kliknutí pravého tlačítka myši na příslušný 
symbol vývojového diagramu. Pro programování robotů tak není nutná znalost žádného konkrétního programovacího jazyka, díky grafickému rozhraní tak odpadají i možné problémy s chybnou syntaxí prríkazů apod. Spolu se software RoboPro se na disk zkopírují i ukázkové programy, které je možné využít jak pro vlastní naprogramování robotů, tak i jako příklady a inspiraci pro tvorbu vlastních řídících programů. K dispozici jsou symboly - ikony pro rozhodovací bloky, výkonné př́ḱkazy, logické operátory atd., v programu je možné využívat větvení na základě podmínek, odskoky do podprogramů apod. Ukázka části řídícího programu je na následujícím obrázku:

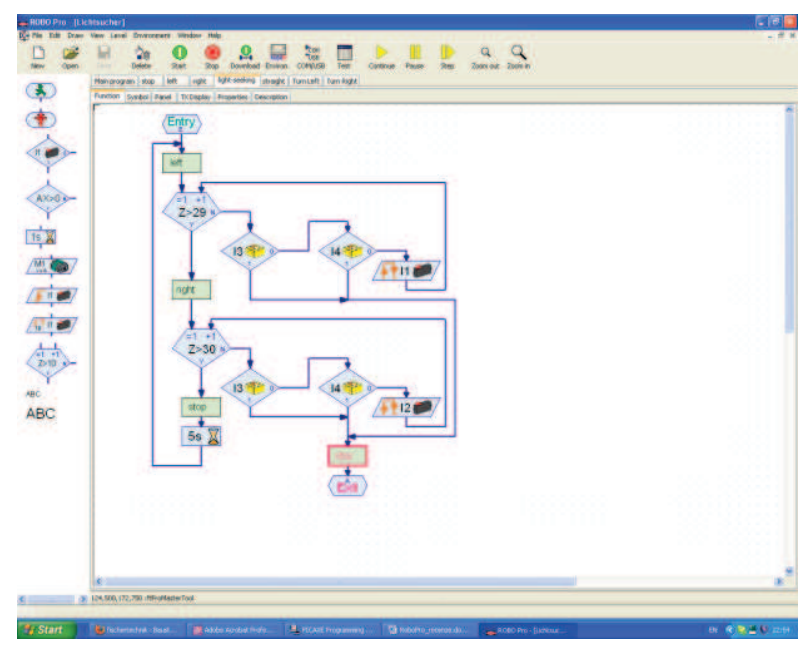

Obr 1: Vývojový diagram části rídícího programu

Dostupnost jednotlivých symbolů a tím i možnosti a složitost vlastního naprogramování je odstupňována do několika úrovní. Pro naprogramování robotů ze stavebnice je postačující základní úroveň „Beginners“ Začátečníci. Celkově je možno říci, že možnosti poskytované software RoboPro (a tedy i možnosti řídící jednotky), značně převyšují možnosti vlastní mechaniky robotů a jejich čidel, dodávaných ve stavebnici. Řídící elektroniku a software by tak bylo pravděpodobně možné využít i pro tvorbu složitějších robotů a zařízení než jsou modely, které je možné sestavit $\mathrm{z}$ dílů dodávaných ve stavebnici.

Bohužel, jak je již uvedeno výše, uživatelské rozhraní RoboPro není k dispozici v češtině, což by snad bylo možné akceptovat pro použití stavebnice na středních školách. Absence českého návodu je však zásadním nedostatkem a bude patrně zásadní překážkou pro využití stavebnice pro výuku na všech typech základních a středních škol.

\section{Závěr}

Stavebnice Robo Mobile Set německého výrobce Fischertechnik nabízí, navzdory jisté nevyváženosti mezi možnostmi konfiguračního software na jedné a mechanické části na druhé straně, vcelku zajímavé možnosti pro výuku základů robotiky nebo polytechnické výchovy obecně ve vyšších ročnících základních škol a na středních školách.

Bohužel, pro využití této stavebnice jsou značně limitující dva $\mathrm{v}$ předchozích odstavcích uvedené problémy.

Prvním je zcela nevyhovující funkce optických senzorů, která omezuje možnosti stavby robotů pouze na modely využívající mechanická čidla (mikrospínače). Vzhledem $\mathrm{k}$ tomu, že pro testování byl $\mathrm{k}$ dispozici pouze jeden exempláŕ stavebnice, není možné s jistotou říci, zda se jednalo o závadu čidel konkrétního kusu stavebnice nebo o obecnou vadu. Faktem zůstává, že s dodaným vzorkem nebylo možno plně využít všech možností.

Druhým problémem je absence českého návodu. Praxe, která je akceptovatelná a běžná u programů pro konfiguraci komerčních průmyslových PLC systémů (tj. dokumentace dostupná pouze $\mathrm{v}$ angličtině nebo němčině) není akceptovatelná u výukové stavebnice, určené žákům základních škol. Povinnost dodávat český návod navíc prodejci či dovozci výslovně ukládá zákon na ochranu spotřebitele č. 634/92 Sb., prodejce se tedy při prodeji stavebnice bez českého návodu dopouští porušení tohoto zákona. Stavebnici tak mohou využít pouze ty školy, které mají $\mathrm{k}$ dispozici příslušně jazykově vybaveného lektora $\mathrm{s}$ alespoň základní orientací v problematice programování rídících automatů. Vzhledem k realitě našeho školství nelze takovou kombinaci považovat za standard, uvedenou stavebnici proto nelze pro obecné zavedení jako výukové pomůcky na základních a středních školách doporučit.

\section{Literatura}

[1] Fischertechnik - Bausteine fürs Leben [online]. 2010 [cit. 2010-09-15]. Computing. Dostupné z WWW: <http://www.fischertechnik.de/de/>.

\section{Ing.Soňa Neradová \\ Fakulta elektrotechniky a informatiky \\ Katedra Softwarových Technologií \\ Univerzita Pardubice \\ Náměstí Čs. legií 565, 53210 Pardubice \\ Tel. +420 466037223 \\ E-mail: sona.neradova@upce.cz}

